\title{
BIOCHIMICA et BIOPHYSICA ACTA
}

\section{BIOMEMBRANES}

\author{
INTERNATIONAL JOURNAL OF BIOCHEMISTRY AND BIOPHYSICS \\ REVUE INTERNATIONALE DE BIOCHIMIE ET BIOPHYSIQUE \\ INTERNATIONALE ZEITSCHRIFT FÜR BIOCHEMIE UND BIOPHYSIK
}

\author{
EDITORIAL BOARD
}

H.R.V. Arnstein (London)

A.D. Bangham (Babraham)

A.J. Barrett (Cambridge)

C.C.F. Blake (Oxford)

R.L. Blakley (Iowa City)

N.K. Boardman (Canberra)

S.L. Bonting (Nijmegen)

P. Bornstein (Seattle)

P. Borst (Amsterdam)

L. Bosch (Leiden)

J. Brachet (Brussels)

A.E. Braunstein (Moscow)

J. Bremer (Oslo)

D.H. Brown (St. Louis)

M.M. Burger (Basel)

P.N. Campbell (London)

E.S. Canellakis (New Haven)

H.N. Christensen (Ann Arbor)

R.D. Cole (Berkeley)

C.F. Cori (Boston)

R.W. Cowgill (Winston-Salem)

F.L. Crane (Lafayette)

R.K. Crane (Piscataway)

P. Cuatrecasas (Res. Tri. Park)

J. Daly (Bethesda)

J. de Gier (Utrecht)

P. Desnuelle (Marseilles)

R.F. Doolittle (La Jolla)

S. Ebashi (Tokyo)

A. Ehrenberg (Stockholm)

L. Ernster (Stockholm)

H. Faillard (Saarbrücken)

E.F. Gale (Cambridge)

J.L. Gaylor (Ithaca)

J. Gergely (Boston)

F. Gibson (Canberra)

G.A. Gilbert (Birmingham)

W.B. Gratzer (London)

O. Greengard (Boston)

M. Gruber (Groningen)

M. Grunberg-Manago (Paris)

H. Gutfreund (Bristol)

D.J. Hanahan (San Antonio)

W. Hasselbach (Heidelberg)

J.N. Haw thorne (Nottingham)

E. Heinz (Frankfurt)

H.C. Hemker (Maastricht)
H.G. Hers (Louvain)

G. Hind (Upton)

S.B. Hladky (Cambridge)

C.M. Jackson (St. Louis)

S.T. Jacob (Hershey)

V. Jagannathan (Poona)

O. Jardetzky (Stanford)

P. Joliot (Paris)

P. Jollès (Paris)

P.W. Jungblut (Wilhelmshaven)

M.D. Kamen (Los Angeles)

K.A. Karlsson (Göteborg)

M. Kates (Ottawa)

Y. Kaziro (Tokyo)

B. Ke (Yellow Springs)

A. Kepes (Paris)

S.C. Kinsky (St. Louis)

A. Kleinzeller (Philadelphia)

M. Klingenberg (Munich)

H.A. Krebs (Oxford)

M.D. Lane (Baltimore)

C.P. Lee (Detroit)

L.F. Leloir (Buenos Aires)

W.J. Lennarz (Baltimore)

S. Lissitzky (Marseilles)

F. Lynen (Munich)

H.M. McConnell (Stanford)

F. Maley (Albany)

K.A. Marcker (Aarhus)

R.D. Marshall (London)

V. Massey (Ann Arbor)

A. Meister (New York)

J.C. Metcalfe (Cambridge)

G.L. Mills (London)

A. Monroy (Naples)

J.F. Morrison (Canberra)

A. Neuberger (London)

L.W. Nichol (Canberra)

P. Nicholls (St. Catherines)

G.L. Nicolson (Irvine)

R.C. Nordlie (Grand Forks)

S. Numa (Kyoto)

B.W. O'Malley (Houston)

A.I. Oparin (Moscow)

L.E. Orgel (San Diego)

L. Packer (Berkeley)

S. Papa (Bari)
D.F. Parsons (Buffalo)

D.S. Parsons (Oxford)

H. Peck (Athens, Ga.)

P.G.W. Plagemann (Minneapolis)

D.J. Prockop (New Brunswick)

G.K. Radda (Oxford)

H. Rasmussen (New Haven)

J. Roche (Paris)

M.R.J. Salton (New York)

H.J. Schatzmann (Bern)

J. Seelig (Basel)

J.K. Setlow (Upton)

N. Sharon (Rehovoth)

B. Shore (Livermore)

D. Shugar (Warsaw)

K. Siddle (Cardiff)

P. Siekevitz (New York)

J. Sjövall (Stockholm)

V.P. Skulachev (Moscow)

E.C. Slater (Amsterdam)

F. Snyder (Oak Ridge)

F. Sorm (Prague)

W.D. Stein (Jerusalem)

R.H. Stellwagen (Los Angeles)

W. Stoeckenius (San Francisco)

F.B. Straub (Budapest)

J.M. Tager (Amsterdam)

C.A. Thomas (Boston)

T.E. Thompson (Charlottesville)

S.N. Timasheff (Waltham)

P.O.P. Ts'o (Baltimore)

A. Tzagoloff (New York)

D.W. Urry (Birmingham, Ala.)

L.L.M. van Deenen (Utrecht)

D.A. van Dorp (Vlaardingen)

D. Vazquez (Madrid)

E.C. Webb (Sydney)

C. Weissmann (Zürich)

R. Whittam (Leicester)

R.J.P. Williams (Oxford)

A.R. Williamson (Glasgow)

H.G. Windmueller (Bethesda)

T. Yonetani (Philadelphia)

H.G. Zachau (Munich)

D.B. Zilversmit (Ithaca)

Vol. 470 (1977) 


\section{AUTHOR INDEX}

Akera, T. and Cheng, V.-J.K.

A simple method for the determination of affinity and binding site concentration in receptor binding studies (470) 412

Alpers, D.H., see Seetharam, B. (470) 424

Banerjee, S.P., Sharma, V.K. and Kung, L.S $\beta$-Adrenergic receptors in innervated and denervated skeletal muscle (470) 123

Benz, R., see Janko, K. (470) 8

Bhakdi-Lehnen, B., see Bhakdi, S. (470) 35

Bhakdi, S., Bhakdi-Lehnen, B. and Bjerrum, O.J.

Detection of amphiphilic proteins and peptides in complex mixtures. Chargeshift crossed immunoelectrophoresis and two-dimensional charge-shift electrophoresis (470) 35

Bjerrum, O.J., see Bhakdi, S. (470) 35

Blayney, L., Thomas, H., Muir, J. and Henderson, A.

Critical reevaluation of murexide technique in the measurement of calcium transport by cardiac sarcoplasmic reticulum (470) 128

Boekhout, M., see van Heerikhuizen, $H$. (470) 453

Born, G.V.R., see Feinberg, H. (470) 317

Borochov, H., Zahler, P., Wilbrandt, W. and Shinitzky, M.

The effect of phosphatidylcholine to sphingomyelin mole ratio on the dynamic properties of sheep erythrocyte mem. brane (470) 382

Borst-Pauwels, G.W.F.H., see Roomans, G.M. (470) 84

Bulat, P., see Snyder, L.M. (470) 290

Butterfield, D.A.

Electron spin resonance investigations of membrane proteins in erythrocytes in muscle diseases. Duchenne and myotonic muscular dystrophy and congenital myotonia (470) 1

Caputo, C., see DiPolo, R. (470) 389

Carafoli, E., see Caroni, P. (470) 437

Caroni, P., Gazzotti, P., Vuilleumier, P., Simon, W. and Carafoli, E.
$\mathrm{Ca}^{2+}$ transport mediated by a synthetic neutral $\mathrm{Ca}^{2+}$-ionophore in biological membranes (470) 437

Cheng, V.J.K., see Akera, T. (470) 412

Cheung, J.Y., Regen, D.M., Schworer, M.E., Whit field, C.F. and Morgan, H.E.

Anaerobic stimulation of sugar transport in avian erythrocytes (470) 212

Chrzeszczyk, A., Wishnia, A. and Springer, Jr., C.S.

The intrinsic structural asymmetry of highly curved phospholipid bilayer membranes (470) 161

Cossins, A.R.

Adaptation of biological membranes to temperature. The effect of temperature acclimation of goldfish upon the viscosity of synaptosomal membranes (470) 395

Dahl, G., see Gratzl, M. (470) 45

Dawson, R.M.C., see Higgins, J.A. (470) 342

Day, E.P., Ho, J.T., Kunze, Jr., R.K. and Sun, S.T.

Dynamic light scattering study of calcium-induced fusion in phospholipid vesicles (470) 503

DeBusk, A.G., see Rao, T.K. (470) 475

De Gier, J., see Mombers, C. (470) 152

De Gier, J., see van Dijck, P.W.M. (470) 58

De Kruijff, B., see Lancée-Hermkens, A.M.W. (470) 141

Demel, R.A., see Read, B.D. (470) 325

DiPolo, R. and Caputo, C.

The effect of ATP on calcium efflux in dialyzed barnacle muscle fibres (470) 389

Edelstein, L., see Snyder, L.M. (470) 290

Eger, R. and Rifkin, D.B.

The preparation and use of pyridoxal $\left[{ }^{32} \mathrm{P}\right]$ phosphate as a labeling reagent for proteins on the outer surface of membranes (470) 70

Ermishkin, L.N., Kasumov, Kh.M. and Potseluyev, V.M.

Properties of Amphotericin B channels in a lipid bilayer (470) 357

Eto, S., see Ikehara, Y. (470) 202 
Feinberg, H., Sandler, W.C., Scorer, M., Le Breton, G.C., Grossman, B. and Born, G.V.R.

Movement of sodium into human platelets induced by ADP (470) 317

Finin, V.S., see Konev, S.V. (470) 230

Fisher, L.E. and Koch, G.

Partial characterization and proposed mode of action of inhibitory HeLa cell surface polypeptides (470) 113

Fisher, M.M., see Waite, M. (470) 134

Fortier, N.L., see Snyder, L.M. (470) 290

Gazzotti, P., see Caroni, P. (470) 437

Geyer, R.P., see Mulligan, J.J. (470) 92

Ghosh, S.K. and Koenig, E.

Isolation of non-myelin plasma membranes unique to white matter (470) 104

Gratzl, M., Dahl, G., Russell, J.T. and Thorn, N.A.

Fusion of neurohypophyseal membranes in vitro (470) 45

Grosse, R., see Vogel, F. (470) 497

Grossman, B., see Feinberg, H. (470) 317

Haydon, D.A., Hendry, B.M., Levinson, S.R. and Requena, J.

Anaesthesia by the n-alkanes. A comparative study of nerve impulse blockage and the properties of black lipid bilayer membranes (470) 17

Henderson, A., see Blayney, L. (470) 128

Hendry, B.M., see Haydon, D.A. (470) 17

Higgins, J.A. and Dawson, R.M.C.

Asymmetry of the phospholipid bilayer of rat liver endoplasmic reticulum (470) 342

Ho, J.T., see Day, E.P. (470) 503

Hoshiko, T., see Valenzeno, D.P. (470) 273

Ikehara, Y., Takahashi, K., Mansho, K., Eto, S. and Kato, $\mathrm{K}$.

Contrast manifestation of alkaline phosphatase and $5^{\prime}$-nucleotidase in plasma membranes isolated from rat liver and ascites hepatoma (470) 202

Irving, C.S. and Lapidot, A.

The dynamic structure of the Escherichia coli cell envelope as probed by ${ }^{15} \mathrm{~N} \mathrm{nu}$ clear magnetic resonance spectroscopy (470) 251

Israelachvili, J.N., Mitchell, D.J. and Ninham, B.W.

Theory of self-assembly of lipid bilayers and vesicles (470) 185

Iyer, $R$.

Plasmid mediated alterations in composi- tion and structure of envelopes of Escherichia coli B/r (470) 258

Janko, K. and Benz, R.

Properties of lipid bilayer membranes made from lipids containing phytanic acid (470) 8

Kaper, A.J., see van Dijck, P.W.M. (470) 58

Karvaly, B. and Loshchilova, E.

Comments on the quantitative interpretation of biomembrane structure by Raman spectroscopy (470) 492

Kasumov, Kh.M., see Ermishkin, L.N. (470) 357

Kato, K., see Ikehara, Y. (470) 202

Kirillov, V.A., see Konev, S.V. (470) 230

Koch, G., see Fisher, L.E. (470) 113

Koenig, E., see Ghosh, S.K. (470) 104

Kojima, K., see Sato, C. (470) 446

Konev, S.V., Volotovskii, I.D., Finin, V.S., Kulikov, A.V., Kirillov, V.A. and Zaichkin, E.I.

The structural transitions of erythrocyte membranes induced by cyclic A.MP (470) 230

Kotyk, A. and Stružinský, R.

Effect of high substrate concentrations on active transport parameters (470) 484

Kulikov, A.V., see Konev, S.V. (470) 230

Kung, L.S., see Banerjee, S.P. (470) 123

Kunze, Jr., R.K., see Day, E.P. (470) 503

Lagaly, G., Weiss, A. and Stuke, E.

Effect of double-bonds on bimolecular films in membrane models (470) 331

Lancée-Hermkens, A.M.W. and de Kruijff, B.

${ }^{14} \mathrm{C}$ NMR measurements of unsonicated phosphatidylcholine bilayers of different fatty acid and sterol composition (470) 141

Lapidot, A., see Irving, C.S. (470) 251

Le Breton, G.C., see Feinberg, H. (470) 317

Levinson, S.R., see Haydon, D.A. (470) 17

Liu, S.C., see Snyder, L.M. (470) 290

Loshchilova, E., see Karvaly, B. (470) 492

Luna, E.J. and McConnell, H.M.

Lateral phase separations in binary mixtures of phospholipids having different charges and different crystalline structures (470) 303

Lynch, R.D., see Mulligan, J.J. (470) 92

Maghrabi, R.El., see Waite, M. (470) 134 
Mannella, C.A. and Parsons, D.F.

Small-angle $\mathrm{X}$-ray scattering from mitochondria (470) 242

Mansho, K., see Ikehara, Y. (470) 202

McConnell, H.M., see Luna, E.J. (470) 303

Meyer, H.W., see Vogel, F. (470) 497

Mitchell, D.J., see Israelachvili, J.N. (470) 185

Mombers, C., van Dijck, P.W.M., van Deenen, L.L.M., de Gier, J. and Verkleij, A.J.

The interaction of spectrin actin and synthetic phospholipids (470) 152

Moog, F., see Seetharam, B. (470) 424

Morgan, H.E., see Cheung, J.Y. (470) 212

Muir, J., see Blayney, L. (470) 128

Mulligan, J.J., Lynch, R.D., Schneeberger, E.E. and Geyer, R.P.

Utilization of exogenous linolenic and oleic acids for plasma membrane phosphoglyceride synthesis in L-fibroblasts (470) 92

Ninham, B.W., see Israelachvili, J.N. (470) 185

Nishizawa, K., see Sato, C. (470) 446

Oonk, H.A.J., see van Dijck, P.W.M. (470) 58

Palek, J., see Snyder, L.M. (470) 290

Parsons, D.F., see Mannella, C.A. (470) 242

Potseluyev, V.M., see Ermishkin, L.N. (470) 357

Rao, T.K. and DeBusk, A.G.

An inducible acetate transport system in Neurospora crassa conidia (470) 475

Read, B.D., Demel, R.A., Wiegandt, H. and van Deenen, L.L.M.

Specific interaction of concanavalin A with glycolipid monolayers (470) 325

Regen, D.M., see Cheung, J.Y. (470) 212

Renooij, W. and van Golde, L.M.G.

The transposition of molecular classes of phosphatidylcholine across the rat erythrocyte membrane and their exchange between the red cell membrane and plasma lipoproteins (470) 465

Repke, K.R.H., see Vogel, F. (470) 497

Requena, J., see Haydon, D.A. (470) 17

Rifkin, D.B., see Eger, R. (470) 70

Roomans, G.M. and Borst-Pauwels, G.W.F.H. Interaction of phosphate with monovalent cation uptake in yeast (470) 84

Russell, J.T., see Gratzl, M. (470) 45

Sandler, W.C., see Feinberg, H. (470) 317
Sato, C., Kojima, K. and Nishizawa, K.

Translocation of hyaluronic acid in cell surface of cultured mammalian cells after X-irradiation and its recovery by added adenosine triphosphate (470) 446

Schneeberger, E.E., see Mulligan, J.J. (470) 92

Schworer, M.E., see Cheung, J.Y. (470) 212

Scorer, M., see Feinberg, H. (470) 317

Seetharam, B., Yeh, K.-Y., Moog, F. and Alpers, D.H.

Development of intestinal brush border membrane proteins in the rat (470) 424

Sharma, V.K., see Banerjee, S.P. (470) 123

Shinitzky, M., see Borochov, H. (470) 382

Simon, W., see Caroni, P. (470) 437

Sisson, P., see Waite, M. (470) 134

Smith, R.

Non-covalent cross-linking of lipid bilayers by myelin basic protein. A possible role in myelin formation (470) 170

Synder, L.M., Liu, S.C., Palek, J., Bulat, P., Edelstein, L., Srivastava, S.K. and Fortier, N.L.

Partition of catalase and its peroxidase activities in human red cell membrane. Effect of ATP depletion (470) 290

Springer, Jr., C.S., see Chrzeszczyk, A. (470) 161

Srivastava, S.K., see Snyder, L.M. (470) 290

Stružinský, R., see Kotyk, A. (470) 484

Stuke, E., see Lagaly, G. (470) 331

Sun, S.T., see Day, E.P. (470) 503

Takahashi, K., see Ikehara, Y. (470) 202

Thomas, H., see Blayney, L. (470) 128

Thorn, N.A., see Gratzl, M. (470) 45

Trudell, J.R.

The membrane volume occupied by anesthetic molecules. A reinterpretation of the erythrocyte expansion data (470) 509

Valenzeno, D.P. and Hoshiko, T.

Potassium reaccumulation by isolated frog epidermis (470) 273

Van Deenen, L.L.M., see Mombers, C. (470) 152

Van Deenen, L.L.M., see Read, B.D. (470) 325

Van Dijck, P.W.M., see Mombers, C. (470) 152

Van Dijck, P.W.M., Kaper, A.J., Oonk, H.A.J. and de Gier, J.

Miscibility properties of binary phosphatidylcholine mixtures. A calorimetric study (470) 58 
Van Golde, L.M.G., see Renooij, W. (470) 465

Van Heerikhuizen, H., Boekhout, M. and Witholt, B.

Proline transport activity in Escherichia coli membrane vesicles of different buoyant densities (470) 453

Verkleij, A.J., see Mombers, C. (470) 152

Vogel, F., Meyer, H.W., Grosse, R. and Repke, K.R.H.

Electron microscopic visualization of the arrangement of the two protein components of $\left(\mathrm{Na}^{+}+\mathrm{K}^{+}\right)$-ATPase (470) 497

Volotovskii, I.D., see Konev, S.V. (470) 230

Vuilleumier, P., see Caroni, P. (470) 437

Waite, M., Sisson, P., Maghrabi, R.El., Yousef, I.M. and Fisher, M.M.

Monoacylglycerol acyltransferase activity in the rat liver plasmalemma fractions (470) 134

Weiss, A., see Lagaly, G. (470) 331

Whitfield, C.F., see Cheung, J.Y. (470) 212

Wiegandt, H., see Read, B.D. (470) 325

Wilbrandt, W., see Borochov, H. (470) 382

Wishnia, A., see Chrzeszczyk, A. (470) 161

Witholt, B., see van Heerikhuizen, H. (470) 453

Wright, G.H.

Changes in plasma membrane enzyme activities during liver regeneration in the rat $(470) 368$

Yeh, K.-Y., see Seetharam, B. (470) 424

Yousef, I.M., see Waite, M. (470) 134

Zahler, P., see Borochov, H. (470) 382

Zaichkin, E.I., see Konev, S.V. (470) 230 
Biochimica et Biophysica Acta, 470 (1977) 45-57

(C) Elsevier/North-Holland Biomedical Press

BBA 77804

\title{
FUSION OF NEUROHYPOPHYSEAL MEMBRANES IN VITRO
}

\author{
MANFRED GRATZL, GERHARD DAHL, JAMES T. RUSSELL * and NIELS A. THORN \\ Departments of Physiological Chemistry and Physiology I, University of Saarland, \\ 6650 Homburg/Saar (G.F.R.) and Institute of Medical Physiology C, University \\ of Copenhagen, Copenhagen (Denmark)
}

(Received February 18th, 1977)

\section{Summary}

Freeze cleaving electron microscopy has shown that fusion of isolated secretory vesicles from bovine neurohypophyses was induced by $\mathrm{Ca}^{2+}$ in micromolar concentrations. $\mathrm{Mg}^{2+}$ and $\mathrm{Sr}^{2+}$ were ineffective. $\mathrm{Mg}^{2+}$ inhibited $\mathrm{Ca}^{2+}$-induced fusion.

In suspensions containing secretory vesicles as well as sheets of cell membrane, release of vasopressin parallel to intervesicular fusion and fusion of secretory vesicles with sheets of cell membrane was observed after exposure to $\mathrm{Ca}^{2+}$. $\mathrm{Mg}^{2+}$ and $\mathrm{Sr}^{2+}$ were ineffective in replacing $\mathrm{Ca}^{2+}$ as trigger for fusion or vasopressin release.

Intervesicular fusion and exocytotic profiles were observed when isolated neurohypophyses or neurosecretosomes were exposed to cold.

\section{Introduction}

It is well established that the passage of $\mathrm{Ca}^{2+}$ across the cell membrane is a critical step in stimulus-secretion coupling in the neurohypophysis $[1,2,3]$. Although $\mathrm{Ca}^{2+}$ influx is apparently too small to be reliably quantitated [4], experiments with $\mathrm{Ca}^{2+}$ transport inhibitors [2] bear out this contention. Also, treatment of isolated neurohypophyses with ionophores, which increase intracellular, free $\mathrm{Ca}^{2+}$ concentration by increasing transmembrane transport, can induce secretion $[5,6]$. Both ultrastructural $[7]$ and biochemical $[8,9]$ studies suggest that secretion in the neurohypophysions as in various other endocrine systems [10], occurs by exocytosis. However, the events that are triggered by

Address correspondence to: Prof. Dr. Manfred Grat $\%$, Department of Physiological Chemistry, University of Saarland, D-6650 Homburg/Saar, G.F.R.

* Present address: Department of Biochemistry, St. Louis University, 1402 South Grand Boulevard, St. Louis, Missouri, 63104, U.S.A. 
$\mathrm{Ca}^{2+}$ leading to exocytosis are not resolved.

Fusion of neurosecretory vesicles with the cell membrane in stimulated cells is well documented in thin section [7] and freeze cleaving electron microscopy $[11,12,13]$. Using the latter technique, intervesicular fusion of isolated secretory vesicles from the islets of Langerhans [14], liver [15] and adrenal medulla [16] was demonstrated when $\mathrm{Ca}^{2+}$ in micromolar concentrations was added. Intervesicular fusion was also observed intracellularly in stimulated pancreatic B-cells [17], and other secretory cells [18-24].

In this study we report the fusion of isolated neurosecretory vesicles with each other after exposure to low concentrations of $\mathrm{Ca}^{2+}$. In addition we investigated the interaction of neurosecreotry vesicles with sheets of cell membrane as well as the release of vasopressin.

\section{Materials and Methods}

Preparation and cold stimulation of rat neurohypophyses

Rats were decapitated with scissors. The neural lobe was dissected out under a binocular microscope and incubated for $15 \mathrm{~min}$ in ice-cold Krebs-Henseleit solution.

\section{Preparation and cold stimulation of bovine neurosecretosomes}

Neurohypophyses were obtained within 20 min of the death of the animals from the Copenhagen Public Slaughterhouse and were transported within 20 $\min$ at $23^{\circ} \mathrm{C}$ to the laboratory. A fraction enriched in neurosecretosomes was isolated according to the method described by Bindler et al. [25] with a few modifications: the neural lobes were freed of connective tissue as well as adherent intermediate lobe tissue and minced in a medium containing sucrose (250 $\mathrm{mM}$ ), and $N$-Tris (hydroxymethyl)methyl-2-aminoethanesulfonic acid $(20 \mathrm{mM}), \mathrm{pH}$ 7.3. The mince was homogenized in a Potter Elvehjem type homogenizer using a teflon pestle (clearance $0.279 \mathrm{~mm}$ ) which was modified as described previously [25]. This homogenization involved 6 up and down strokes at $1000 \mathrm{rev} . / \mathrm{min}$ using a Technidrive English Electric DC motor. The homogenate was centrifuged at $700 \times g$ for $10 \mathrm{~min}$ in an MSE high speed centrifuge. The supernatant was recovered using a Pasteur pipette and stored. The pellet was suspended in $2 \mathrm{ml}$ homogenization medium, rehomogenized using a pestle with a clearance of $0.102 \mathrm{~mm}$ (4 strokes, $1000 \mathrm{rev} . / \mathrm{min}$ ) and centrifuged again at $700 \times g$ for $10 \mathrm{~min}$. The supernatant was collected, pooled with the initial supernatant and centrifuged at $1700 \times g$ for $15 \mathrm{~min}$. The pellet contained the neurosecretosome enriched fraction. The supernatant was discarded. During the homogenization steps the tube was surrounded by ice. All the centrifugation procedures were carried out at room temperature to reduce coldinduced release of vasopressin [26-28].

The neurosecretosome pellet was suspended in a small volume $(0.5 \mathrm{ml} / 2$ neurohypophysis, $15-20 \mathrm{mg}$ protein $/ \mathrm{ml})$ of incubation medium $(\mathrm{NaCl} 126$ $\mathrm{mM} / \mathrm{KCl} 4.8 \mathrm{mM} / \mathrm{CaCl}_{2} 2.8 \mathrm{mM} / \mathrm{MgSO}_{4} 1.3 \mathrm{mM} / N$-2-hydroxyethyl piperazine$N^{\prime}$-2-ethane sulphonic acid (HEPES) $26 \mathrm{mM}$ (pH 7.0)/dextrose $10 \mathrm{mM}$ ). $10 \mu \mathrm{l}$ aliquots of this suspension were transferred to an Eppendorff Microfuge tube ( $1.5 \mathrm{ml}$ capacity) and cooled in crushed ice for $15 \mathrm{~min}$. 
Preparation of isolated bovine neurosecretory vesicles

The procedure for the isolation of a crude secretory vesicle fraction (fraction 3 ) and purified vesicle fraction (fraction D) has been described previously [29]. In the present experiments, however, $10 \mathrm{mM}$ sodium cacodylate was used instead of $20 \mathrm{mM}$ TES to buffer all solutions during the isolation of neurohypophysial fractions. To maintain low $\mathrm{Ca}^{2+}$ concentrations, $5 \mathrm{mM}$ ethyleneglycol-2-(2-aminoethyl)-tetraacetic acid (EGTA) was added to all solutions. The fractions obtained were dialyzed against $10 \mathrm{mM}$ cacodylate buffer $(\mathrm{pH} 7.0)$ containing $250 \mathrm{mM}$ sucrose and $1 \mathrm{mM}$ EGTA (CSE medium). The dialyzed fraction was centrifuged at $2600 \times \mathrm{g}$ for $15 \mathrm{~min}$ in a Beckman L2-65K ultracentrifuge using a 65 rotor. The pellet was suspended in CSE medium, to give a protein concentration of approximately $20 \mathrm{mg} / \mathrm{ml}$.

Incubation of isolated neurosecretory vesicles with media of different cation concentrations

CSE-medium containing various concentrations of $\mathrm{Ca}^{2+}$ ranging from $10^{-8}$ to $10^{-3} \mathrm{M}$ was prepared as described by Portzehl et al. [30]. $\mathrm{Mg}^{2+}$ - and $\mathrm{Sr}^{2+}$-containing solutions were prepared from stock solutions made in CSE medium. To start the reaction $10 \mu \mathrm{l}$ aliquots of fraction 3 or fraction $\mathrm{D}$ was added to $10 \mu \mathrm{l}$ CSE-medium containing the cations under study. Incubation (at $37^{\circ} \mathrm{C}$ ) was carried out for $5 \mathrm{~min}$ and then stopped by the addition of $1.5 \mathrm{ml}$ ice-cold medium of the same cation concentration used during incubation. The total content of the incubation tube was filtered through a millipore filter (pore size $0.22 \mu \mathrm{m})$. The filtrate was assayed for vasopressin released. The amount so determined was compared with the total amount of vasopressin, in the original fraction after extraction with $0.25 \%$ acetic acid in $0.9 \% \mathrm{NaCl}$ [31].

When incubating vesicle fractions for ultrastructural studies the incubation procedure was identical. The reaction was stopped by the addition of the same solution used in the experiment containing, as a fixative, $2 \%$ glutaraldehyde in place of an equal amount of sucrose. The resulting mixture was incubated for $5 \mathrm{~min}$ at $37^{\circ} \mathrm{C}$. Then for cryoprotection $10 \mu \mathrm{l}$ glycerol was added. After 10 $\mathrm{min}$ at room temperature small droplets $(\approx 0.5 \mu \mathrm{l})$ of the suspension were frozen on golden specimen holders in Freon 22 cooled by liquid nitrogen.

\section{Radioimmunoassay of vasopressin and neurophysin}

Antisera raised against synthetic arginine vasopressin (Sandoz, Basel, Switzerland) was kindly donated by Mr. J. Dencker (Royal Pharmaceutical High School, Copenhagen). Arginine vasopressin was iodinated with ${ }^{125} \mathrm{I}$ by the chloramine $\mathrm{T}$ technique [32] and the labelled hormone was purified on DEAE Sephadex-A 25. The assay mix ture contained $100 \mu{ }^{125}$ I-labelled arginine vasopressin $(2000 \mathrm{cpm}), 200 \mu \mathrm{l}$ sample or standard and $300 \mu \mathrm{l}$ antiserum in assay buffer (final dilution in assay tube $1: 100000$ ). The assay buffer consisted of $0.1 \mathrm{M}$ sodium phosphate ( $\mathrm{pH} 7.4$ ) containing bovine serum albumin $1.8 \mathrm{mg} / \mathrm{ml}$. The usual incubation time was $24 \mathrm{~h}$. The antibody-bound arginine vasopressin was separated by ethanol precipitation $(67 \% \mathrm{v} / \mathrm{v}$ final) and centrifugation. Precipitates were counted in a Selectronic (Copenhagen) $\gamma$-spectrometer. All procedures were carried out at room temperature. The standard curves, appropriate blanks and samples were assayed in duplicate. The synthetic arginine vaso- 
pressin used for iodination and as standards was a generous gift by Ferring $\mathrm{AB}$ (Malmö, Sweden), (antidiuretic activity $345 \mathrm{I} . \mathrm{U} . / \mathrm{mg}$ ). The routine sensitivity of the assay was between 25 and $50 \mu \mathrm{U} / \mathrm{ml}(72-144 \mathrm{pg} / \mathrm{ml})$. The cross reactivity of the antiserum with oxytocin was $1 / 300$ of that with arginine vasopressin. Radioimmunoassay of neurophysin was performed as described previously [33]. Protein was assayed by the method of Lowry et al. [34] with crystalline bovine serum albumin as a standard.

\section{Freeze fracturing}

Freeze fracturing and replication were performed in a Balzers BAF 300 device at $-100^{\circ} \mathrm{C}$. Replicas were cleaned in sodium hypochlorite solution and washed in distilled $\mathrm{H}_{2} \mathrm{O}$. They were picked up by Formvar- and carbon-coated 1 hole grids and examined in an electron microscope (Siemens Elmiskop 101) at $100 \mathrm{kV}$. All photographs were printed as positives (platinum depositions: black). The direction of shadowing is indicated by an encircled arrowhead. Fracture faces are denoted according to the nomenclature introduced recently [35].

\section{Results}

Exocytosis in cold-stimulated isolated neurohypophyses and neurosecretosomes

Neurhypophyses are known to release hormones via exocytosis. This process is initiated physiologically by depolarization of the cell membrane. Intense

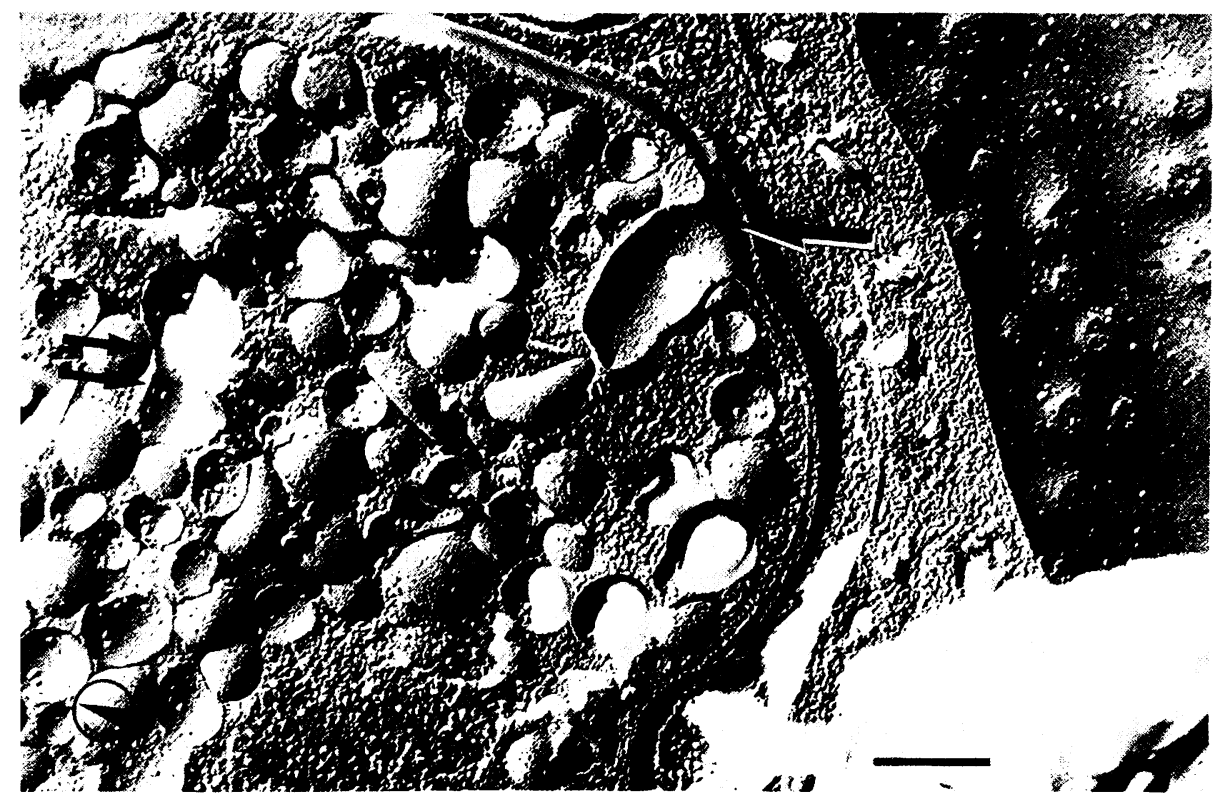

Fig. 1. Freeze-fracture replica showing a nerve ending in the neurohypophysis of a rat. The isolated neurohypophysis was exposed to cold $\left(2^{\circ} \mathrm{C}\right)$ for $15 \mathrm{~min}$. The arrow points to an exocytotic orifice. The large area of the exposed vesicle membrane indicates compound exocytosis. Fused vesicles not in obvious contact with the plasma membrane can also be observed (double arrows). E, Endothelial cell. Magnification $\times 60000$, scale $0.2 \mu \mathrm{m}$. 


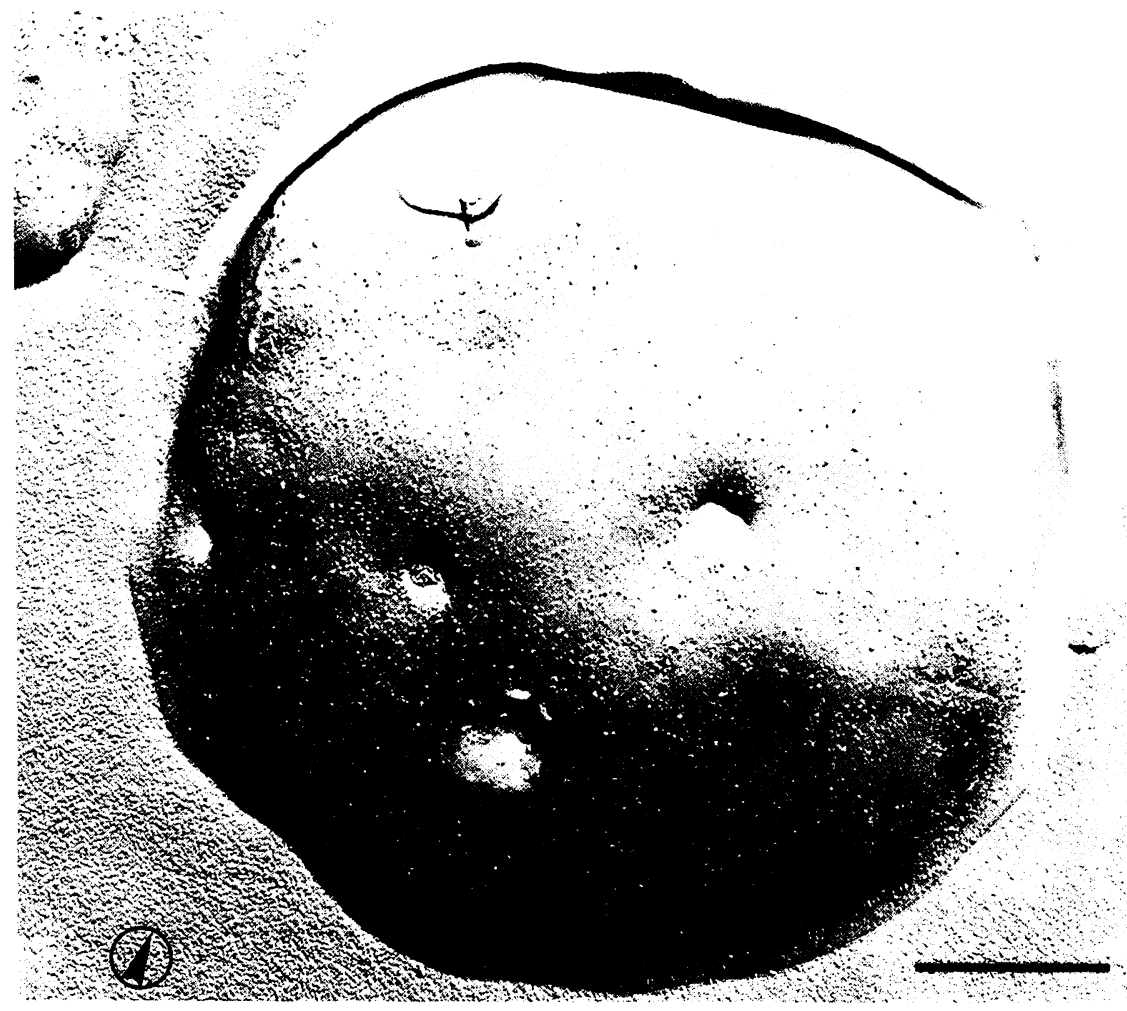

Fig. 2. Electron micrograph of a freeze-fractured preparation of nerve endings from bovine neurohypophyses (neurosecretosomes) exposed to cold $\left(2^{\circ} \mathrm{C}\right)$ for $15 \mathrm{~min}$. The fracture has exposed a large area of the plasma membrane P-face. The presence of several holes indicates exocytotic activity. Magnification $\times 40000$, scale $0.5 \mu \mathrm{m}$.

release of neurohypophyseal hormones also occurs on exposure of the neural lobe or isolated neurosecretosomes to cold [26-28]. In the present experiments depolarization of isolated rat neurohypophyses by $\mathrm{K}^{+}(56 \mathrm{mM})$ or cooling to $0^{\circ} \mathrm{C}$ resulted in the appearance of exocytotic profiles in freeze-fractured neurohypophyses. Exocytosis is characterized by fusion of secretory vesicles with the cell membrane. In addition, fusion of secretory vesicles with other vesicles undergoing exocytosis was observed, as well as fusion of secretory vesicles with each other, where no connection between vesicles and cell membrane was evident. The coincidence of vesicle-cell membrane fusion and intervesicular fusion is called "compound exocytosis". This phenomenon is shown for a cold-stimulated rat neurohypophysis in Fig. 1.

In the neurohypophyses hormones are released from nerve endings of hypothalamic cells. These terminals of the neurosecretory cells can be isolated and are called "neurosecretosomes" [25]. Like the intact cells, neurosecretosomes respond to cold with release of hormones [28]. We have found membrane alterations typical for exocytosis ("necks" and "holes") in the cell membrane of neurosecretosomes after exposure to high $\mathrm{K}^{+}(56 \mathrm{mM})$ or cold (Fig. 2).

Stimulation of neurosecretosomes also results in intervesicular fusion of secretory vesicles as shown in a crossfractured neurosecretosome (Fig. 3). 


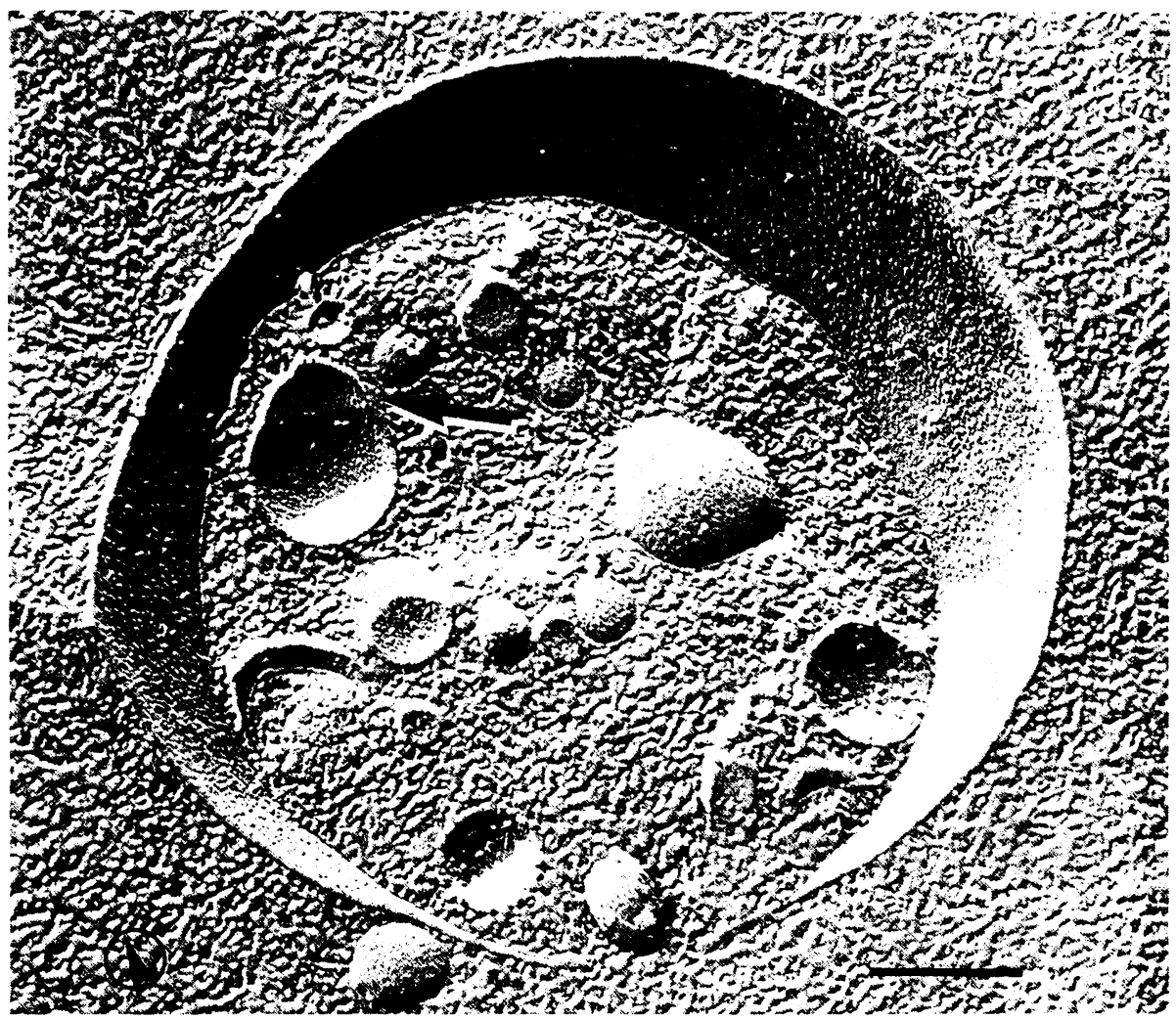

Fig. 3. Cross fractured neurosecretosome after exposure to cold $\left(2^{\circ} \mathrm{C}\right)$ for $15 \mathrm{~min}$. Fused secretory vesicles (arrow) can be observed. Magnification X 80000 , scale $0.2 \mu \mathrm{m}$.

\section{Membrane fusion of neurosecretory vesicles}

Secretory vesicles, isolated as described in Methods by differential and sucrose density centrifugation were found to be dispersed in buffered solutions containing EGTA. This is shown in a freeze fractured vesicle suspension in Fig. 4. The presence of divalent cations $\left(\mathrm{Ca}^{2+}, \mathrm{Mg}^{2+}, \mathrm{Sr}^{2+}\right)$ in the incubation medium resulted in the formation of vesicle clusters. Aggregation of membrane associated particles was observed in the areas of membrane contact (Fig. 5). Furthermore, $\mathrm{Ca}^{2+}$, but not $\mathrm{Mg}^{2+}$ or $\mathrm{Sr}^{2+}$, induced the formation of twinned vesicles. These structures represent fused vesicles since the cleavage plane was continuous from one to the other vesicle both in membrane P- and E-faces. The transition area from one to the other vesicle may or may not exhibit aggregates of membrane associated particles (Fig. $6 \mathrm{a}-\mathrm{d}$ ).

The percentage of fused vesicles as a function of the free $\mathrm{Ca}^{2+}$-concentration is shown in Fig. 7. Vesicle fusion increases between $10^{-7} \mathrm{M} \mathrm{Ca}^{2+}$ and $10^{-4} \mathrm{M}$ $\mathrm{Ca}^{2+}$ and is half maximal around $10^{-6} \mathrm{M} \mathrm{Ca}^{2+}$.

$\mathrm{Mg}^{2+}$ and $\mathrm{Sr}^{2+}$ were not effective in inducing fusion of isolated secretory vesicles. $\mathrm{Mg}^{2+}$ even inhibited the $\mathrm{Ca}^{2+}$-induced fusion apparently in a concentration dependent manner (Table I). 


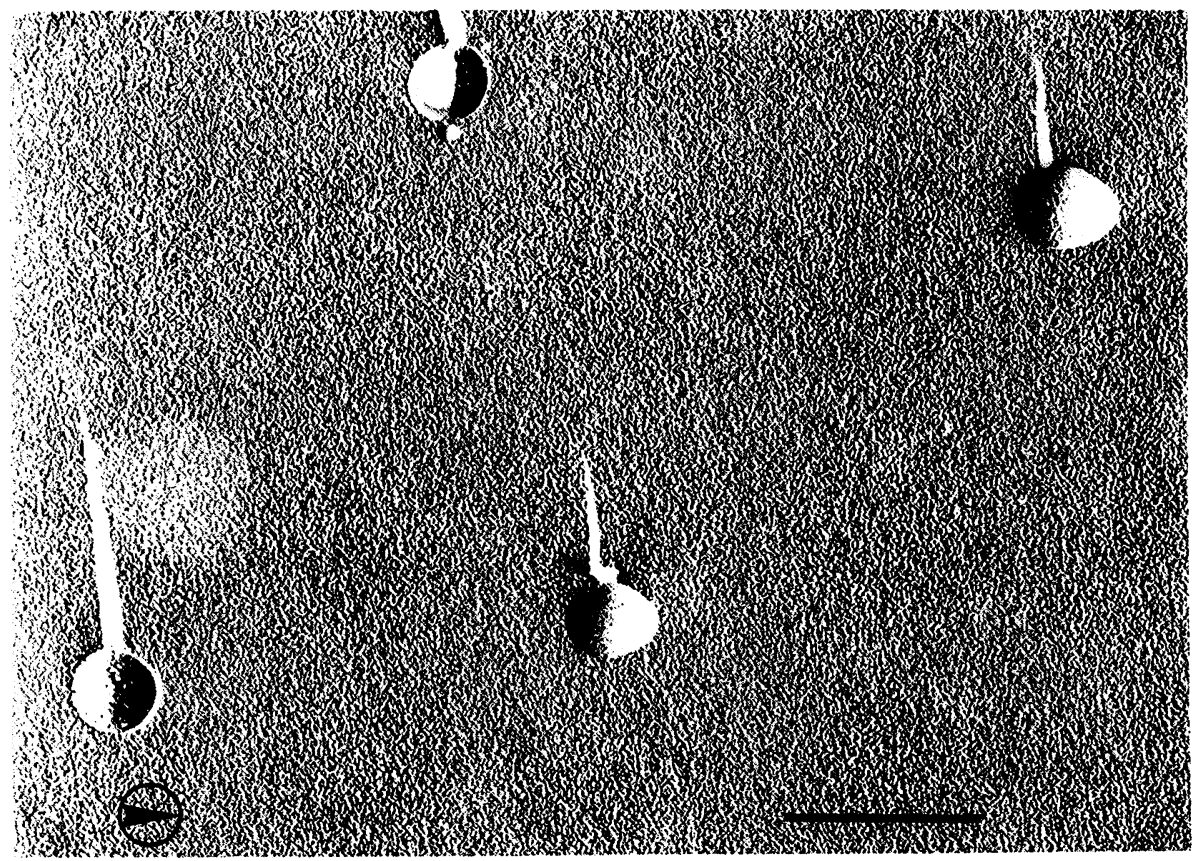

Fig. 4. Electron micrograph of a freeze-fractured suspension of isolated secretory vesicles of the neurohypophysis (fraction $\mathrm{D}$ ) incubated in low $\mathrm{Ca}^{2+}$ concentration $\left(<10^{-8} \mathrm{M}\right)$. The vesicles are dispersed in the medium. The membrane-associated particles are randomly distributed and adhere more to the concave $P$-faces than to the convex E-faces. Magnification $\times 40000$, scale $0.5 \mu \mathrm{m}$.

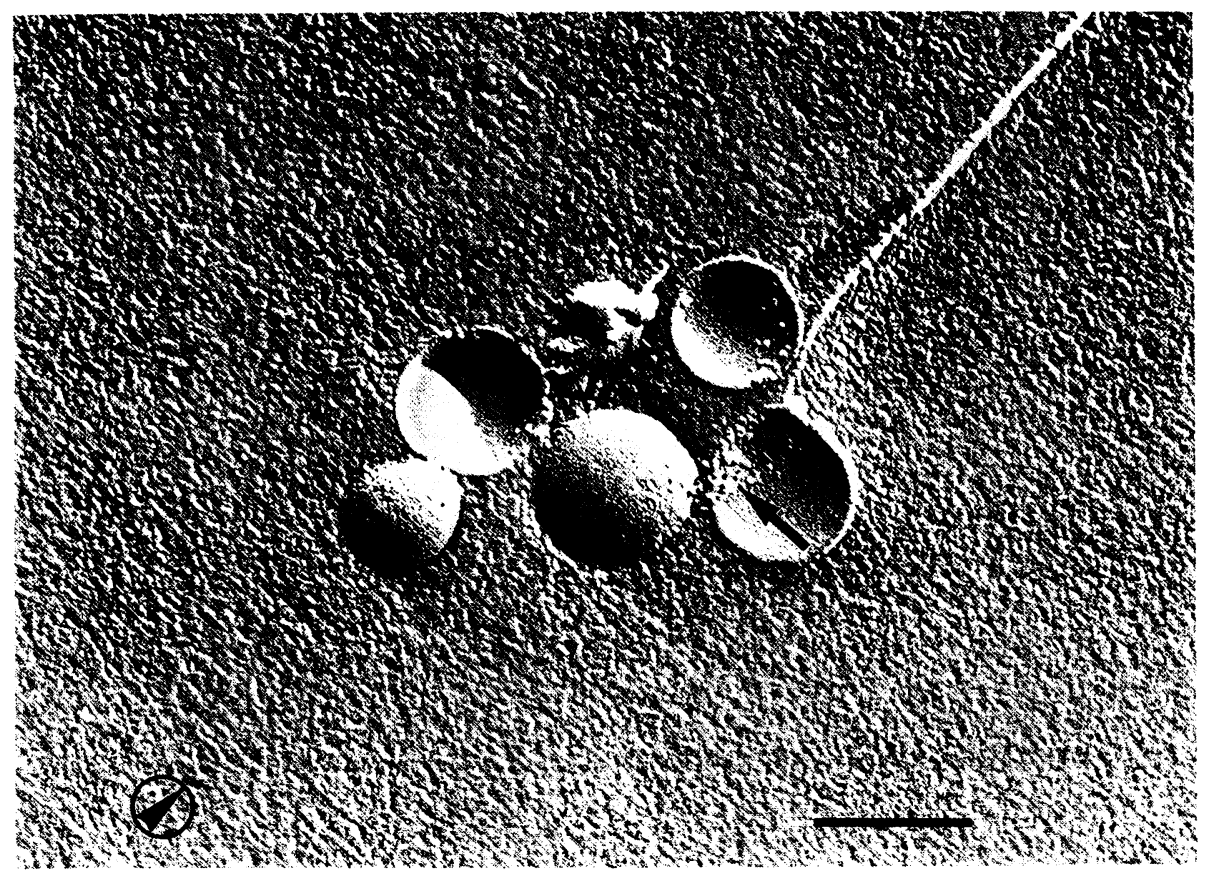

Fig. 5. Freeze-fractured isolated secretory vesicles (fraction D) incubated with $2 \cdot 10^{-5} \mathrm{M} \mathrm{Ca}^{2+}$. The vesicles contact each other forming clusters. In areas of contact, aggregations of membrane associated particles (arrow) can be observed. Magnification $\times 80000$, scale $0.2 \mu \mathrm{m}$. 

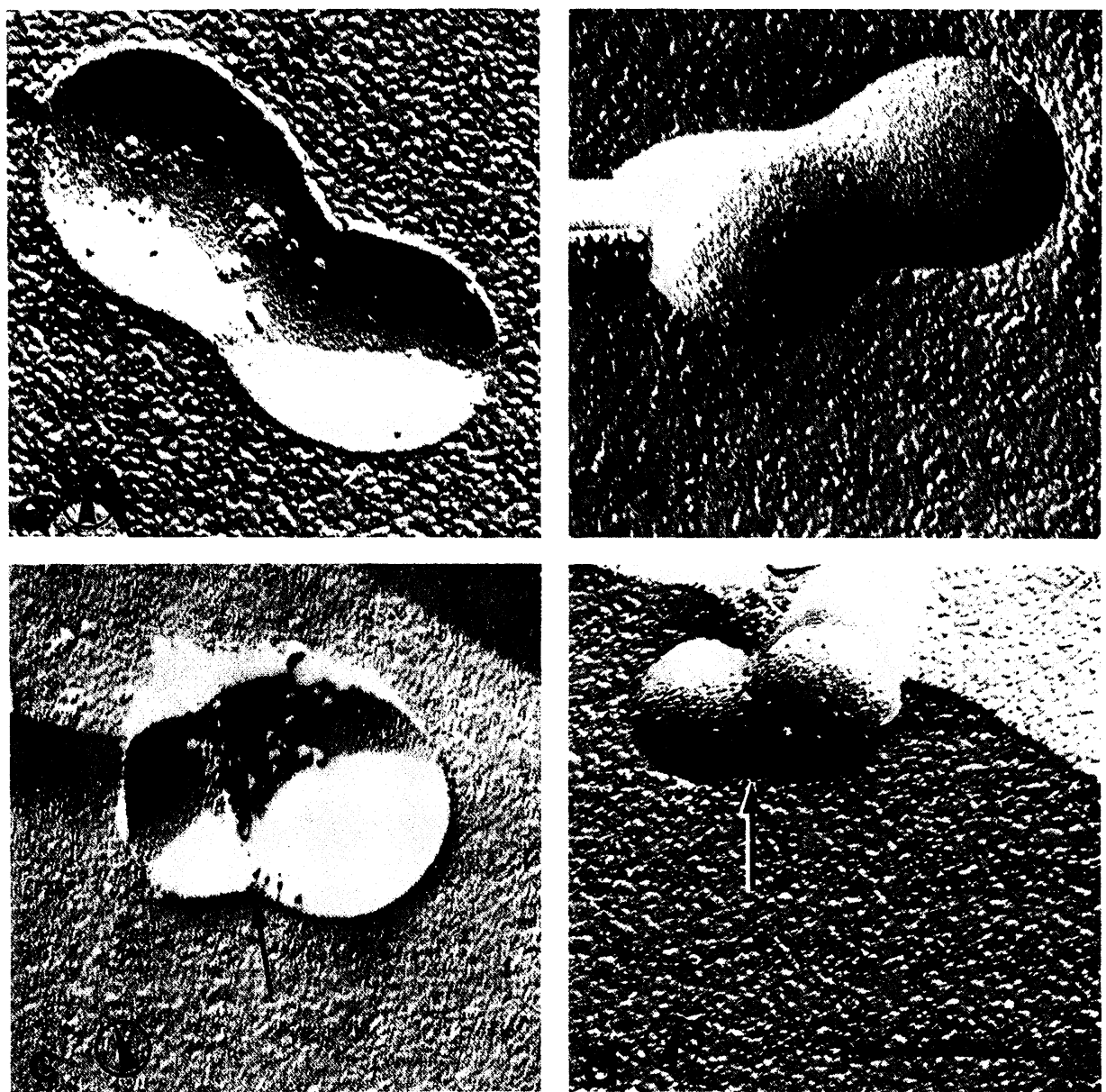

Fig. 6, a-d. Freeze-fractured isolated secretory vesicles (fraction D) incubated in a solution containing $\mathrm{Ca}^{2+}\left(2 \cdot 10^{-5} \mathrm{M}\right)$. Twinned vesicles with a continuous cleavage plane from one to the other vesicle in membrane P- (a and $c$ ) and E-face (b and $d$ ) indicate vesicles fusion. Aggregates of membrane associated particles can be observed (arrows). Magnification $\times 120000$, scale $0.2 \mu \mathrm{m}$.

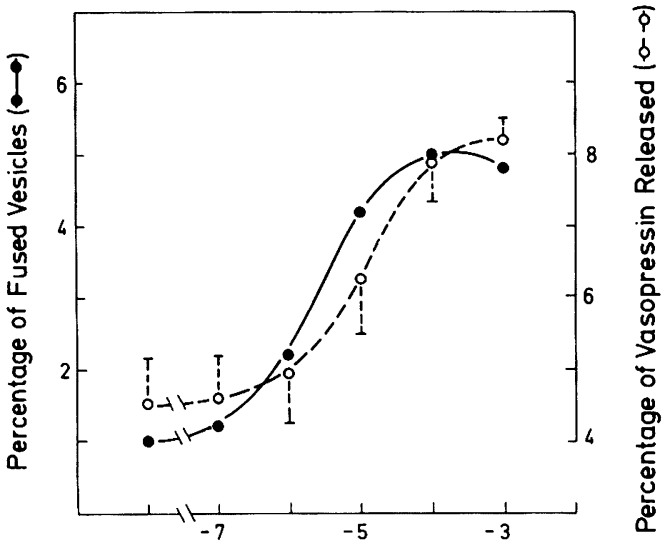

$\log \mathrm{Ca}^{2+}(\mathrm{M})$

Fig. 7. Fusion of secretory vesicles (fraction 3 ) and release of vasopressin induced by increasing concentrations of $\mathrm{Ca}^{2+}$. Fraction 3 was incubated in a medium containing $0.25 \mathrm{M}$ sucrose, $10 \mathrm{mM}$ sodium cacodylate ( $\mathrm{pH}$ 7.0) and $1 \mathrm{mM}$ EGTA (CSE medium). $\mathrm{Ca}^{2+}$ concentrations were adjusted as described [30]. Vesicle fusion was determined by counting 500 vesicles for each incubation. Vasopressin release was measured by radioimmunoassay after millipore filtration of the incubate as described under Methods. The data for vasopressin release are identical to the ones in Table II. 
TABLE I

\section{CATION DEPENDENCE OF THE FUSION OF VESICLES FROM FRACTION D}

The values represent two typical sets of experiments. The experiments were evaluated by counting 500 vesicles for each incubation.

$-$

Cations

Control $\left(<10^{-8} \mathrm{M} \mathrm{Ca}^{2+}\right)$

$10^{-4} \mathrm{M} \mathrm{Ca}^{2+}$

$10^{-4} \mathrm{M} \mathrm{Mg}^{2+}$

$10^{-+} \mathrm{M} \mathrm{Sr}^{2+}$

$10^{-4} \mathrm{M} \mathrm{Ca}^{2+}+10^{-4} \mathrm{M} \mathrm{Mg}^{2+}$

$10^{-4} \mathrm{M} \mathrm{Ca}^{2+}+10^{-3} \mathrm{M} \mathrm{Mg}^{2+}$
Percentage of fused vesicles

$\begin{array}{ll}1.2 & 0.8 \\ 5.4 & 6.0 \\ 1.6 & 1.0 \\ 1.4 & 1.4 \\ & \\ 3.8 & 3.6 \\ 2.6 & 2.8\end{array}$

6.0

1.0

3.6
2.8

TABLE II

VASOPRESSIN RELEASED (\% OF TOTAL CONTENT) FROM FRACTION 3 EXPOSED TO DIFFERENT CONCENTRATIONS OF $\mathrm{Ca}^{2+}, \mathrm{Sr}^{2+} \mathrm{AND} \mathrm{Mg}^{2+}$

For procedures see legend under Fig. 7. Values are mean ( \pm S.E.M. where $n$ equals 3 or more). The number of experiments $(n)$ is given in parentheses.

Percentage of vasopressin released

Cations in the in-

$\mathrm{Ca}^{2+} \mathrm{Sr}^{2+} \mathrm{Mg}^{2+}$

cubation medium

(M)

Control
$\left(<10^{-8} \mathrm{M} \mathrm{Ca}^{2+}\right)$
$10^{-7}$
$10^{-6}$
$10^{-5}$
$10^{-4}$
$10^{-3}$

Control

$10^{-7}$

$10^{-6}$

$10^{-3}$

$\mathrm{Ca}^{2+} \mathrm{Sr}^{2+}$

Membrane fusion and release of secretory product in fraction 3

In conjunction with the electronmicroscopic evaluation we also followed the amount of hormone in the vesicles as well as in the incubation medium. Fraction $\mathrm{D}$, used mainly for the electron microscope studies described above, was a preparation purified from fraction 3 by a density-gradient step [29]. This procedure rendered secretory vesicles fragile as indicated by loss of hormone. Fraction 3 was found to be more stable. As described later this secretory vesicle fraction released vasopressin upon addition of $\mathrm{Ca}^{2+}$ but not of $\mathrm{Mg}^{2+}$ or $\mathrm{Sr}^{2+}$. Electron microscopic inspection of this fraction revealed the presence of sheets of cell membranes among other contaminants of this vesicle preparation. After addition of $\mathrm{Ca}^{2+}$ to fraction 3 , vesicles were found in close contact with membrane sheets and in the area of membrane attachment aggregations of membrane associated particles were observed (Fig. 8a). In addition, vesicles were found to have fused with membrane sheets connecting the vesicle lumen with the surrounding medium (Fig. $8 \mathrm{~b}, \mathrm{c}$ ). 

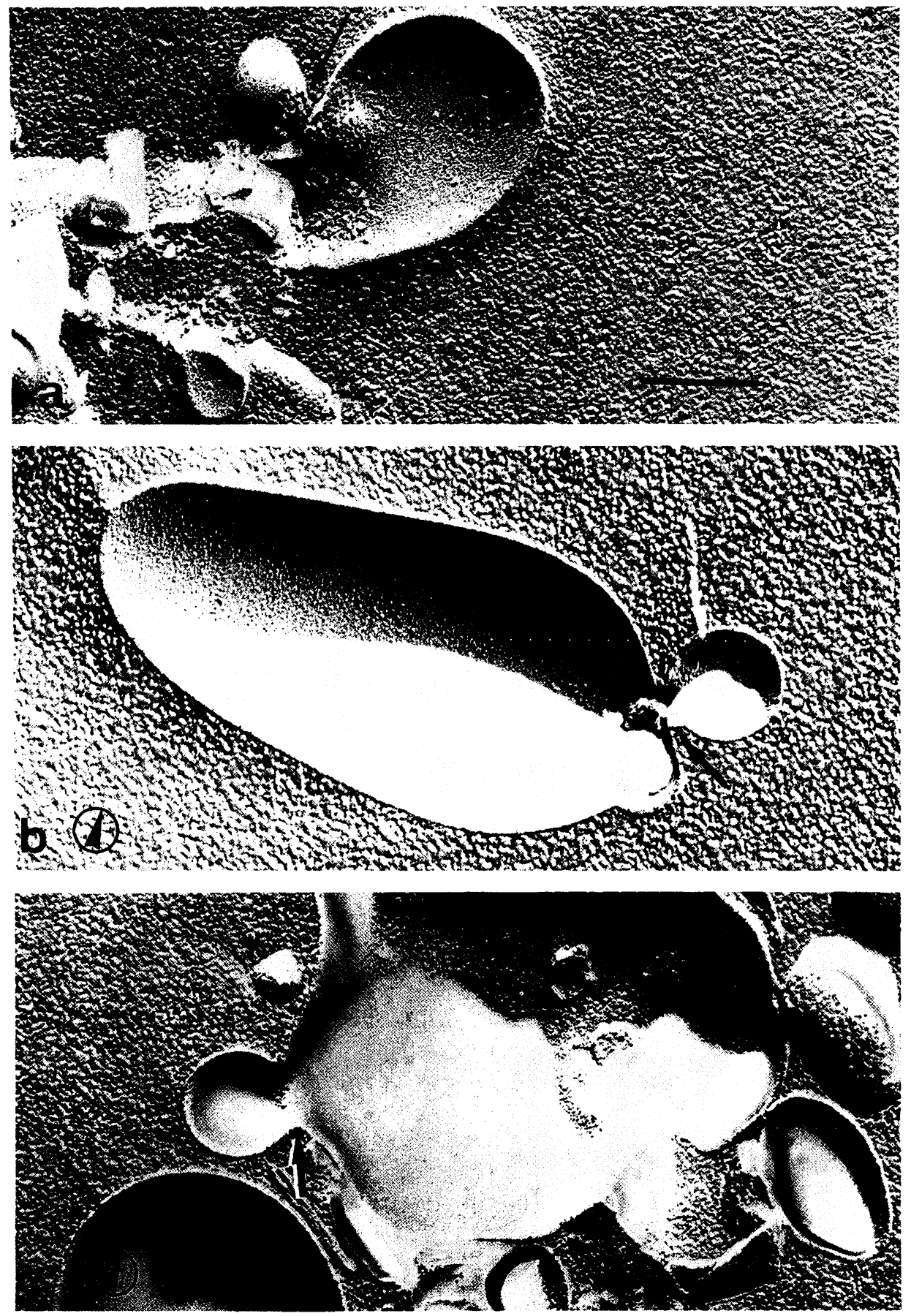

Fig. 8, a-c. Electron micrograph of a freeze-fractured preparation of the neurohypophysis (fraction 3) incubated in $\mathrm{Ca}^{2+}\left(10^{-4} \mathrm{M}\right)$. Secretory vesicles and some sheets of plasma membrane are present ir. this fraction. An aggregation of membrane associated particles can be observed on a vesicle contacting a ne:mbrane sheet (a). Fusions of vesicles with membrane sheets are shown in (b) and (c) (arrows). Magnification $\times 80000$, scale $0.2 \mu \mathrm{m}$. 
The amount of vasopressin released into the medium increased as a function of the $\mathrm{Ca}^{2+}$ concentration (Fig. 7). Half maximal effect was obtained between $10^{-6}$ and $10^{-5} \mathrm{M} \mathrm{Ca}^{2+}$. Fig. 7 shows that fusion of secretory vesicles parallels the observed hormone release when fusion and vasopressin were determined using identical incubation procedures.

In two experiments a similar increase in the release of neurophysin (the intravesicular hormone-binding protein) into the medium was observed. However, the percentage neurophysin released into the medium was significantly lower than that of vasopressin released.

In another set of experiments $\mathrm{Sr}^{2+}$ and $\mathrm{Mg}^{2+}$ instead of $\mathrm{Ca}^{2+}$ was included in the CSE medium. These cations, in the concentrations tested, did not induce vasopressin release from the vesicles (Table II). When $\mathrm{Mg}^{2+}\left(10^{-4} \mathrm{M}\right.$ or $10^{-3} \mathrm{M}$ ) was added to an incubation medium containing $10^{-4} \mathrm{M} \mathrm{Ca}^{2+}$ the release caused by $\mathrm{Ca}^{2+}$ was slightly inhibited.

\section{Discussion}

The physiological stimulus for the release of hormones from the neurohypophyses is depolarization of the cell membrane. Isolated neural lobes and the isolated nerve endings (neurosecretosomes) release large amounts of vasopressin on exposure to $\mathrm{K}^{+}$and cold [26-28]. Biochemical data indicate that this release is an exocytotic event [27,28]. This was confirmed in this study by the appearence of exocytotic profiles in isolated neural lobes and neurosecretosomes when exposed to $\mathrm{K}^{+}$or cold. Furthermore, secretory vesicles fuse with each other during this treatment. This may suggest an accumulation of an intracellular effector leading to membrane fusion.

The requirement of $\mathrm{Ca}^{2+}$ in stimulus-secretion coupling in the neurohypophysis is well documented [1-6]. Experiments with isolated secretory vesicles from endocrine pancreatic tissue [14] liver [15] and adrenal medulla [16] have indicated that $\mathrm{Ca}^{2+}$ is able to act as a final trigger of exocytosis initiating membrane fusion. The present study with secretory vesicles from the neural lobe of the hypophysis makes it seem probable that in this system also $\mathrm{Ca}^{2+}$ controls membrane fusion leading to release of hormone.

The experiments indicate that $\mathrm{Ca}^{2+}$ in micromolar concentrations causes membrane fusion in a "minimal" medium. To compare this in vitro situation with the intracellular environment the influence of $\mathrm{Mg}^{2+}$ and $\mathrm{K}^{+}$on $\mathrm{Ca}^{2+}$. induced fusion needs to be considered.

Despite the fact that monovalent cations such as $\mathrm{K}^{+}$inhibit $\mathrm{Ca}^{2+}$ binding to phospholipid membranes [36] the presence of $60 \mathrm{mM} \mathrm{KCl}$ did not change $\mathrm{Ca}^{2+}$-induced fusion of secretory vesicles isolated from rat liver (Gratzl, M. and Dahl, G., unpublished). The $\mathrm{Mg}^{2+}$ concentration of intact cells is assumed to be high [37]. Transmitter release induced by injection of $\mathrm{Ca}^{2+}$ into the giant synapse was found to be inhibited by simultaneous intracellular application of $\mathrm{Mg}^{2+}$ [38]. As shown in the present study $\mathrm{Mg}^{2+}$ is able to inhibit $\mathrm{Ca}^{2+}$-induced membrane fusion in $10^{-4} \mathrm{M}$ or higher concentrations. As a consequence in intact cells, a shift of the sigmoidal curve, which describes the $\mathrm{Ca}^{2+}$ dependence of membrane fusion, to higher concentrations of $\mathrm{Ca}^{2+}$ can be expected. However, an effect of $\mathrm{Mg}^{2+}$ in the intact cells is difficult to evaluate since the local 
free concentration of $\mathrm{Mg}^{2+}$ is unknown. The free intracellular concentration of $\mathrm{Ca}^{2+}$ is also difficult to determine. Recent experiments using aequorin as intracellular indicator of $\mathrm{Ca}^{2+}$ indicate that the free concentration is $10^{-7} \mathrm{M}$ or less [39-41] but increases during stimulation of the cell [39]. Thus, the $\mathrm{Ca}^{2+}$ concentration dependence of intervesicular fusion is compatible with secretion by intact cells.

In parallel to the fusion of secretory vesicles we have observed the release of vasopressin. There are a number of studies (cited in ref. 42 ) in which attempts were made to release vasopressin from isolated neurosecretory vesicles by adding $\mathrm{Ca}^{2+}$ to the suspension medium. In all these studies the $\mathrm{Ca}^{2+}$ concentrations employed were high and the reproducibility of the biological assays was problematic.

It would appear unlikely that the increase in hormone release observed in this study could have originated from neurosecretosomes present in the crude granule fraction for the following reasons: the half maximal concentration of $\mathrm{Ca}^{2+}$ in the extracellular medium required for $\mathrm{K}^{+}$stimulated release from neurohypophysis is $5 \cdot 10^{-4} \mathrm{M}$ [1] which is $10-100$ times higher than the concentrations used here. Furthermore, under the incubation conditions employed no depolarization occurs. In fact, increasing $\mathrm{Ca}^{2+}$ concentrations should hyperpolarize neurosecretosomes [43]. Under the centrifugation conditions used, neurosecretosomes would have been spun down at lower $g$-values than secretory vesicles, and indeed neurosecretosomes could not be detected in the fractions examined by electron microscopy. Lastly, the purified vesicle fractions were devoid of lactate dehydrogenase, a marker enzyme for such elements $[29,44]$.

The almost identical $\mathrm{Ca}^{2+}$ concentrations' dependence for both fusion and release suggests a cause and effect phenomenon. The specificity of the $\mathrm{Ca}^{2+}$ effect and the antagonism by $\mathrm{Mg}^{2+}$ argues against the release being a reflection of a general leakiness.

Fusion of two vesicles should lead to formation of a common lumen and not to any loss of material into the surrounding medium. Sheets of cell membrane have been found in fraction 3. Interactions of secretory vesicles with such sheets have been shown to occur (Fig. 8). Allthough the infrequency of this observation prevented a quantitative evaluation, the fusion of secretory vesicles with sheets of cell membrane at least would contribute to the observed release of hormone.

The fact that $\mathrm{Sr}^{2+}$ cannot induce membrane fusion is interesting since injection of $\mathrm{Sr}^{2+}$ into giant synapses did cause transmitter release [38]. Also, in studies of the release of oxytocin from rat neurohypophyses $\mathrm{Sr}^{2+}$ could replace $\mathrm{Ca}^{2+}$. when applied extracellularly [45]. However, in both these investigations cell systems were used so that an intracellular redistribution of $\mathrm{Ca}^{2+}$ by $\mathrm{Sr}^{2+}$ cannot be ruled out.

In conclusion, both the release of hormone from neurosecretory vesicles in the presence of sheets of cell membrane and membrane fusion are characterized by the requirement of low concentration of $\mathrm{Ca}^{2+}, \mathrm{Ca}^{2+}$-specificity, and inhibition by $\mathrm{Mg}^{2+}$. These results suggest an in vitro exocytosis type reaction. The molecular mechanisms involved in this $\mathrm{Ca}^{2+}$-induced release are currently under investigation in our laboratories. 


\section{Acknowledgements}

The authors thank Mrs. M. Elis, Mrs. I. Kümmel and Mr. R. Weiss as well as Mrs. B. Lynderup Christensen and Miss E. Engberg for excellent technical assistance. We are indebted to Dr. P. Traylor for expert help in preparing this manuscript. This work was supported by Deutsche Forschungsgemeinschaft, Sonderforschungsbereich 38 'Membranforschung', Bonn-Bad Godesberg.

\section{References}

1 Douglas, W.W. and Poisner, A.M. (1964) J. Physiol. 172, 19-30

2 Russell, J.T. and Thorn, N.A. (1974) Acta Endocr. 76, 471-487

3 Dreifuss, J.J. and Nordmann, J.J. (1974) Bull. Acad. Suisse Sci. Med. 30, 107-117

4 Russell, J.T. and Thorn, N.A. (1974) Acta Endocr. 76, 449-470

5 Russell, J.T., Hansen, E.L. and Thorn, N.A. (1974) Acta Endocr. 77, 443-450

6 Robinson, I.C.A.F., Russell, J.T. and Thorn, N.A. (1976) Acta Endocr. 83, 36-49

7 Nagasawa, J., Douglas, W.W. and Schultz, R.A. (1970) Nature 227, 407-409

8 Matthews, E.K., Legros, J.J., Grau, J.D., Nordmann, J.J. and Dreifuss, J.J. (1973) Nat. New Biol. 241, 86-87

9 Edwards, B.A., Edwards, M.E. and Thorn, N.A. (1973) Acta Endocr. 72, 417-424

10 Douglas, W.W. (1974) in Secretory Mechanisms of Exocrine Glands (Thorn, N.A. and Petersen, O.H., eds.), pp. 116-129. Copenhagen, Munksgaard

11 Dreifuss, J.J., Akert, K., Sandri, C. and Moor, H. (1976) Cell and Tiss. Res. 165, 317-325

12 Dempsey, G.P., Bullivant, S. and Watkins, W.B. (1973) Z. Zellforsch. 143, 465-484

13 Dreifuss, J.J., Nordmann, J.J., Akert, K., Sandri, C. and Moor, H. (1974) in Proc. VI Intern. Symposium on Neurosecretion. Springer Verlag, Berlin

14 Dahl, G. and Gratzl, M. (1976) Cytobiologie 12, 344-355

15 Gratzl, M. and Dahl, G. (1976) FEBS Lett. 62, 142-145

16 Dahl, G., Gratzl, M. and Ekerdt, R. (1976) J. Cell Biol. 70, 180a

17 Berger, W., Dahl, G. and Meissner, H.P. (1975) Cytobiologie 12, 119-139

18 Amsterdam, A., Ohad, J. and Schramm, M. (1969) J. Cell Biol. 41, 753-773

19 De Virgilis, G., Meldolesi, J. and Clementi, F. (1968) Endocrinology 83, 1278-1284

20 Ekholm, R., Zelander, T. and Edlund, Y. (1962) J. Ultrastruc. Res. 7, 61-72

21 Ichikawa, A. (1965) J. Cell Biol. 24, 369-385

22 Normann, T.C. (1970) Aspects of Neuroendocrinology, (Bargmann, W. and Scharrer, B., eds.), pp. 30-42 Springer Verlag, Berlin

23 Röhlich, P., Anderson, P. and Uvnäs, B. (1971) J. Cell Biol. 51, 465-483

24 Andrew, R.D. and Shivers, R.R. (1976) J. Morph. 150, 253-278

25 Bindler, E., LaBella, F.A. and Sanwal, M. (1967) J. Cell Biol. 34, 185-205

26 Douglas, W.W. and Ishida, A. (1965) J. Physiol. 179, 185-191

27 Hong, J.S. and Poisner, A.M. (1974) Endocrinology 94, 234-240

28 Baker, R., Vilhardt, H. and Hope, D.B. (1975) J. Neurochem. 24, 1091-1093

29 Russell, J.T. and Thorn, N.A. (1975) Acta Physiol. Scand. 93, 364-377

30 Portzehl, H., Caldwell, P.C. and Rüegg, J.C. (1964) Biochim. Biophys. Acta 79, 581-591

31 Stürmer, E. (1968) in Handb. Exp. Pharmakol. (Berde, B. ed.), 23, p. 135

32 Greenwood, F.C., Hunter, W.M. and Glover, J.S. (1963) Biochem. J. 89, 114-123

33 Robinson, J.C.A.F., Russell, J.T. and Thorn, N.A. (1976) Acta Endocr. 83, 36-49

34 Lowry, O.H., Rosebrough, N.J., Farr, A.L. and Randall, R.J. (1951) J. Biol. Chem. 193, 265-275

35 Branton, D., Bullivant, S., Gilula, N., Karnovsky, M., Moor, H. Mühlethaler, K., Northcote, N., Packer, L., Satir, B., Satir, P., Speth, V., Staehlin, L. and Weinstein, R. (1975) Science 190, 54-56

36 Hauser, H. and Dawson, R.M.C. (1967) Eurp. J. Biochem. 1, 61-69

37 Baker, P.F. and Craw ford, A.C. (1972) J. Physiol. 227, 855-874

38 Miledi, R. (1973) Proc. R. Soc. Lond. B. 183, 421-425

39 Llinás, R. and Nicholson, C. (1975) Proc. Natl. Acad. Sci. U.S. 72, 187-190

$\Delta 0$ Dipolo, R., Requena, J., Brinley, F.K., Mullins, L.J., Scarpa, A. and Tiffert, T. (1976) J. Gen. Physiol. $67,433-467$

41 Rose, B. and Löwenstein, W.R. (1976) J. Membrane Biol. 28, 87-119

42 Vilhardt, H. and Tondevold, E. (1972) Acta Endocr. 70, 625-635

43 Peterson, O.H. and Ueda, N. (1973) J. Physiol. 254, 583-606

44 Dean, C.R. and Hope, D.B. (1967) Biochem. J. 104, 1082-1088

45 Buch, M., Dreifuss, J.J., Grau, J.D. and Nordmann, J.J. (1972) J. Physiol. 222, 168P-169P 